\title{
VIKTÓRIA LINDER*
}

\section{Balancing between the Career and Position-based Systems. Some Aspects of Recent Developments in Civil Service Legislation in Hungary}

\begin{abstract}
This article analyses some aspects of the wavering course the Hungarian civil service is taking between the career and position-based systems. Since the turn of the new millennium a number of new measures have been introduced in civil service legislation. These reforms have pushed the employment system of the civil service in two directions simultaneously. While some of the new elements have aimed at dismantling what had been a quite typical career-based system, others have further entrenched it. These very frequent, detailed, but less than consistent amendments to the civil service legislation have resulted in a climate of uncertainty. It remains to be seen which tendency will prevail in the coming years.
\end{abstract}

Keywords: civil service legislation, career and position-based systems, modernisation attempts in HRmanagement

\section{Historical backgrounds before the naissance of the organic civil service code, in brief}

The first steps towards creating a professional civil service in Hungary were taken in the third quarter of the 19th century. Since that time a great number of measures have been implemented to regulate the legal relationships of state employees. Up until the outbreak of the First World War, a strongly career based civil service system was created in our country, with all of characteristics of the Weberian-type civil service, regulated by many arborescent legal instruments. No unified civil service code has existed to date, but every element of the ideal-typical career civil service system ${ }^{1}$ was regulated, except what is surely the most important one: for the recruiting and selection of civil servants there existed no unified regularization. ${ }^{2}$

The career civil service system existed until the end of the Second World War. After the subsequent elections, the winning communist party wanted to control all the important

* Ph.D., Research fellow, ECOSTAT Institute for Research of Economy and Society, H-1024 Budapest, Margit krt. 85.

E-mail: viktoria.linder@t-online.hu

1 Bekke, H. A. G. M.-van der Meer, F. M.: Civil Service Systems in Western Europe. CheltenhamNorthampton, (MA), 2000; Gajduschek, Gy.: Közszolgálat. A magyar közigazgatás személyi állománya és személyzeti rendszere az empirikus adatok tükrében (Civil Service. On the Personnel and Personnel System of the Hungarian Public Administration with empirical Data). Budapest, 2008; Weber, M.: Gazdaság és társadalom 1 (Economy and Society I). Budapest, 1987.

${ }^{2}$ Lörincz, L.: A személyzeti politika változásának szakaszai a magyar közigazgatásban 1945 után (The Changes of Periods in Personnel Policy in the Hungarian Public Administration after 1945). Budapest, 1986; Lőrincz, L.: A szocialista zsákmányrendszertöl a merit-system küszöbéig (From the Spoil System in Socialism until the Door-step of the Merit-system.). In: Lörincz, L.: A magyar közszolgálat. Közigazgatási szakemberképzés a XX. században (Hungarian Civil Service. Training of Public Administration Experts in the XXth Century). Budapest, 1995. 
posts in public administration and thus polish off the ancien régime. So, the public administration became "cleared" of all of the professional civil servants of the "rotten" old regime. The newly created posts were filled with faithful party-comrades, no matter if they were ill-educated and incompetent at carrying out the tasks of administration. The direct and inevitable consequence of these actions was the radical and disastrous decrease in the working standards of the administration. ${ }^{3}$ As in those days it was the state, which exclusively owned all companies, the communist party proclaimed that there was no need to regulate the employment relationships of people serving in administration differently to those of other employees working in any branch of the economy. Legally speaking, by using the fiction of all employees working for the state-no matter if they worked in industry, agriculture, education or administration-all belonged organically under the scope of the nationwide applicable, unitary labour code. From the 70s and 80s onwards, however, it was gradually recognized that the tasks of public administration differ in several respects from other occupations. Consequently, various measures were taken over the years in order to accentuate the differences in the regulation of these employment relationships (this has also been the case concerning other branches of state power-courts, state attorney offices, etc.).

\section{The advent of the organic civil service code}

During the period of political transition in the 1990s Hungary, was the first country in the Central Eastern European region to accept a new form of civil service regulation. ${ }^{4}$ After the collapse of the communist regime, for the new democratic states in transition there were plenty of Western examples to choose from in shaping the basic institutions of the new rule of law, taking into consideration the requirements of the division of power, etc. This was also the case in shaping the new structure of public service. As the transition period in Hungary ran in parallel with the first steps of Europeanization in creating the new personnel system in public administration, there existed a need to settle it in a way which suited the standards of the European Union, too. For the Central and Eastern European Countries, the forming of the new personnel policy first of all meant the need to conceptualize a new set of principles for the civil service. After the change of regime in Hungary the new, democratically elected Parliament had to answer several fundamental questions. So, it was necessary to decide whether it was rational to regulate the employment relationships of public employees differently from the general labour code. (As was mentioned earlier, in the last years before the change of regime the differences became increasingly evident.) Furthermore, the question of how to delimit the notion of public service demanded an answer-in order to decide whether all employees of the state and municipalities should belong under the scope of a single framework code, or whether the different categories of the public service should be subject to different codes depending on their various special characteristics. There was also another question to be answered, namely, where the regulatory dividing line between elected officers and employed professionals lay. Finally, there was the fundamental question of where to draw the demarcation line between the political sphere and the executive power.

${ }^{3}$ Lörincz.: A személyzeti politika változásának szakaszai... (The Changes of Periods in Personnel Policy...). op. cit; Lőrincz: A szocialista zsákmányrendszertöl... (From the Spoil System in Socialisme...). op. cit.

4 Balázs, I.: Rugalmasság a közigazgatásban (Flexibility in Public Administration). In: Fogarasi, J. (ed.): A közigazgatás személyi állománya (The Personnel of Public Administration). Budapest, 1995. 
In response to these questions and the prevailing circumstances the Hungarian Parliament gave their answer in 1992, by accepting several codes regulating the employment relationships of different categories of persons employed by the state and private sectors. This year also saw the passing of code No 23 of 1992 regulating the legal relationships of the civil service organically, but separately from the employees belonging under the scope of the general labour code and also separately from other categories of the public service, who-depending on their status and special characteristics-belonged under the scope of other codes. The code on the civil service enumerated the types and specified the concrete organs which employed civil servants. These were the organisations of the public administration on central, territorial and local level-both in the state administration and in municipalities. (In addition there are some offices of other state organs which also employ civil servants to run the offices of these state organs. ${ }^{5}$ ) Other categories of public employees include public servants, judges, state attorneys, officers of armed forces, etc.-their legal status and employment relationships are regulated by separate laws. In Hungary elected officers do not fall under the notion of "public employee". The basic and "background" law for employment relationships is the Labour Code.

The civil service code passed in 1992 was the first in Hungary to regulate the legal and employment relationships of civil servants organically, but many other legal instruments (government decrees, decisions, etc.) have appeared which complement it. The structure of the civil service regulation of 1992 aimed to create a career civil service system-similar to the one which had existed until the end of World War II. In most of its dispositions and arrangements it has also succeeded in fulfilling this endeavour. This regulation, under the scope of public law, determined the different elements of civil servants' employment relationship, such as admission requirements, career development, promotion and remuneration, the training and appraisal system, the question of life-time tenure and dismissal, etc. However, as was also the case with the regulation from the inter-war period, this code did not address the question of access to the civil service; that is, recruitment and selection as a whole. ${ }^{6}$

\section{The context of modernisation efforts in the civil service after the millennium}

Turning to the most important developments in Hungarian civil service legislation after the millennium, several factors ought to be mentioned, which prompted the new measures and also correlated with each other. These factors are part of the constant endeavour to motivate civil servants better, with the aim of enhancing their performance, in order to cut down the expenditures and costs of the public sector, and at the same time to meet the needs of citizens for a better public administration in the 21 st century. These ideas are very common in discussions about civil service modernisation in the whole of the developed world. The

5 After 18 years of this type of categorization, from June 2010 a new law (No LVIII of 2010 on the status of civil servants of central government) has come into force after being passed by the newly elected Parliament. This law draws several distinctions between the civil servants of the organs belonging to the central government and those of municipalities and other state organs. This paper does not analyse this newly published legislation.

${ }^{6}$ Linder, V.: Versenyvizsgák a közigazgatásban (Councours in Public Administration). Magyar Közigazgatás, (2006) 12; Lőrincz, L.: Kiválasztás a közigazgatásban (Selection in Public Administration). Magyar Közigazgatás, (2000) 6. és (2000) 8; Lőrincz, L.: A közigazgatás alapintézményei (Basic Institutions of the Public Administration). Budapest, 2005. 
tools for accomplishing these tasks have also been widely tested since the 1980s. Since then, in the course of different civil service reforms in various countries there have been many attempts to adapt the human resources management tools used in the private sphere to the needs of the public sector. The idea behind this was that public servants-including civil servants-should be motivated by the same measures as ordinary people employed on labour market; that the rigidity of the normatively regulated, non-responsive carrier systems should be lessened, and that civil servants should be personally interested in working and serving in a more effective and efficient way.

In a mere 20 years, since 1992, the Hungarian civil service code has been amended more than 70 times. $^{7}$ The most important amendments and at the same time the most relevant ones-in connection with the dichotomy mentioned in the title of this article-the career vs. position-based systems-have been introduced since the millennium. From that time onward the most committed believers in civil service modernisation have introduced a lot of new measures in the Hungarian civil service legislation, hoping to solve-at least partially-the problems of the costly, slow acting civil service. These deep seated problems, which were far from new, could not be deal with in one or even several blows. The modernisation measures introduced "from abroad" were not new. The countries, which began to apply these internationally known, quite similar modernisation attempts in the course of the 1980s and 1990s have by now accumulated a wealth of experience. But these experiences have also been enough to declare that these initiatives were not the "miracle cures" for all of the problems of the civil service. ${ }^{8}$ The slogans heard in the Hungarian civil service during the last decade were the same as those proclaimed in Western countries,

7 Hazafi, Z.: A karrier rendszerü szabályozás múltja, jelene, jövője a közigazgatásban a köztisztviselök jogállására vonatkozó törvény változásainak tükrében (The Past, Present and Future of the Career-type Regulation in Public Administration, with Special Regards to the Changes of Civil Service Act). Budapest, 2006.

8 See for example Bouckaert, G.: La réforme de la gestion publique change-t-elle les systèmes administratifs? Revue française d'administration publique, (2003) 105-106; Bouckaert, G.: Moderniser l'État. La route à suivre. Le Commentaire. Revue Internationale des Sciences Administratives, 72 (2006) 3; Bouckaert, G.: Changing World, Changing Public Administration: New European Trends. Conference Paper. Budapest, 2009; Gajduschek, Gy.: Egyéni teljesítményértékelés a magyar közigazgatásban. Egy funkcionális elemzés (Personal Performance Evaluation System in the Hungarian Public Administration. A Functional Analysis). Vezetéstudomány, 38 (2007) 1, Gajduschek, Gy.: A köztisztviselő munkájának értékelése: a magyar jogi szabályozás és a gyakorlat elemzése az empirikus adatok tükrében (Evaluation of the Civil Servant's Work: Analysis of Empirical Data in Respect of the Regulation and Praxis in Hungary). Humánpolitikai Szemle, (2007) 11-12; Gajduschek: Közszolgálat... (Civil Service). op. cit.; Haque, M. S.: Moderniser l'État. La Route à Suivre. Sa Contribution et sa Critique. Revue Internationale des Sciences Administratives, 72 (2006) 3; Kettl, D. F.: Moderniser l'État. Revue Internationale des Sciences Administratives, 72 (2006) 3; Linder, V.: A magyar közszolgálati humáneröforrás-gazdálkodás nemzetközi összehasonlításban (The Human Resource Management in the Hungarian Civil Service in International Context). Budapest, 2009; Lőrincz, L.: A kormányzás modernizációja (The Modernization of the Government). Magyar Közigazgatás, (2006) 11; Lőrincz, L.: Közigazgatási reformok: mítoszok és realitás (Reforms in Public Administration. Mythes and Reality). Közigazgatási Szemle, (2007) 2; Premfors, R.: Modernising government. The way forward. International Review of Administrative Science, 72 (2006) 3; Talbot, C: Modernising Government: The Way Forward-A Comment. International Review of Administrative Sciences, 72 (2006) 3; OECD: Modernising Government: The Way Forward. Paris, 2005; OECD: Performance-related Pay Policies for Government Employees. Paris, 2005. 
which have tried to solve the problems in their civil services-or speaking in a broader context in their public service-in the 1980s, and consisted mostly of applying the solutions of the New Public Management. However, and despite our late attempts to try to adapt these solutions, we paid scant any attention to the clear warnings that "Context matters". 9 These warnings imply that modernisation efforts, which have met with some success in one country, will not necessarily succeed in others-particularly if the timing, economical and social contexts, cultural and administrative traditions, etc. are not taken into consideration. Another key issue and one of the potential causes of the difficulties with the modernisation efforts in the Hungarian civil service has been the fact that the starting point of every reform measure has always been codification. This has meant that every time a modernisation measure has been introduced, a new legal instrument has been passed or maybe an old one amended. It is hardly surprising then, that when for example a management tool "copied" from private sector human resource management is introduced by legislative tools into a career civil service system, with no significant adaptation or testing, for almost 100 thousand civil servants, from one day to another, is not a success. Indeed, this kind of implanting has proven de-motivating for civil servants. ${ }^{10}$ Several examples of this type of attempt at reform can be found as we will see in the next chapter.

\section{The most important developments in legislation in recent times}

Under the aegis of the modernisation of civil service employment relationships in Hungary, a series of new measures have been introduced by legislative tools over the last decade. Most of these initiatives-following one trend-have aimed to open up the thus far quite strict career system, while others-following a different trend and in other aspects-have tried to reinforce it.

The most relevant guiding principle behind these processes has always been the aim of enhancing the performance of the civil service, in order to better serve the needs of the citizens for a better public administration, and at the same time to realize this task in a less costly manner. The tools for carrying out this endeavour have been first and foremost practices adapted from human resources management in the private sector. In consequence these tools-which have been widely tested in the civil services of many countries in recent years-have been adopted by passage of legislation in Hungary, too. However, due to the fact that the Hungarian legal system is of the German-type, a quite grotesque situation has emerged. Thus, the management tools which were adapted, such as various types of individual personal performance appraisal systems, performance-related pay and competency management have been accompanied by very detailed and exhaustive legal regulation. Furthermore, this regulation has been nationwide and unitary in character-without taking

9 Bouckaert: Moderniser l'État... op. cit.; Haque: Moderniser l'État... op. cit.; Kettle: Moderniser l'État. op. cit.; OECD: Modernising Government ... op. cit.; Premfors: op. cit.; Talbot: op. cit.; OECD: Modernising Government... op. cit.; OECD: Performance-related Pay Policies... op. cit.

${ }^{10}$ Following the collocation of the different stages of convergence in the field of public administration modernisation by Christopher Pollitt, these solutions in Hungary incorporate the socalled »decisional convergence«-when a decision is adopted on the introduction of a measure which fits into a modernisation trend. The phases specified by Pollitt in series are discursive convergence, decisional convergence, practice convergence and results convergence. Pollitt, Ch.: Clarifying Convergence. Striking Similarities and Durable Differences in Public Management Reform. Public Management Review, 3 (2001) 4, 471-492; Pollitt, Ch.: Convergence: The useful myth? Public Administration, 79 (2001) 4, 933-947. 
into consideration the different branches of public administration, local conditions, the type of work, etc. Let us now consider these in greater detail.

In 2001 the organic civil service code was amended in many of its provisions. It was then that the compulsory individual personal performance appraisal system for the whole civil service-including central, territorial and local level, state administration and municipalities ${ }^{11}$-was introduced. At the same time performance-related pay (PRP) was connected with this process. According to the provisions of the code, the head of the organisations of public administration had the right to adjust civil servants' annual salaries by as much as minus or plus $20 \%$, according to the results of their performance appraisal. ${ }^{12 ; 13}$ Of course, the payment of the performance related pay also depended on the financial circumstances of the public administration organ. According to the results of research carried out by the Hungarian Institute of Public Administration ${ }^{14}$ after the introduction of performance related pay, the civil servants were initially keen on it and felt motivated by the new HR-instrument, which sought to replace the existing rigid system of remuneration connected to seniority. After some years of experience, however, the results have been disappointment and demotivation: the causes of the failures were just the same as in other countries that had introduced PRP earlier, for example not enough budgetary tools for compensating good performance, ${ }^{15}$ deficiencies in measuring performance objectively, inequity in distribution among the organisations, but also among organisational units or civil servants, too many administrative tasks associated with the appraisal system, etc.

Having confronted the failures in the functioning of PRP, but having then failed to remedy them, the government decided to implement a new individual personal performance appraisal system alongside the old one. From 2007 onwards, another type of personal performance appraisal system was gradually introduced for civil servants of the central state administration. This type of appraisal system was connected to the payment of bonuses. The new individual personal performance appraisal system involved a very complicated process, implying also a lot of administrative tasks for evaluated civil servants, as well as for managers and HR staff. To give an example of the complexity of the system, the new type of appraisal was meant to take place 4 times per year (including the self-appraisal of the civil servant), then at the end of the year a 5th, complex appraisal was to be carried out, including the whole-year evaluation of the civil servant. When it came to awarding bonuses, depending on the budgetary tools of the public administration organ, the number of civil servants awarded was pre-determined at different levels, using different methods. ${ }^{16}$ The amounts of the bonuses awarded also depended on the salary of the civil servant. The calculation method for civil servants differs from that of managers; it is of course more advantageous for the latter. Despite the name of this HR-tool, the new performance appraisal system doesn't measure only the civil servants' performance itself, but also his/her comportment and the development of his/her competency level. This means that performance management, competency management and performance related pay have all been included

11 Up to 100 thousands civil servants then.

12 The process of the performance appraisal have taken place at the end of the year.

13 This rate is quite higher then the average in international praxis.

14 After decades of existence the Institute was dissolved in 2006.

15 In spite of the absence of satisfactory budgetary tools, the rate of the performance related pay has been modified in the code later up to $-20 \%-+30 \%$.

16 In fact, civil servants awarded by bonuses are few in numbers, but the amounts awarded for the few are quite high (although, in consequence of budgetary restrictions, they have been cut back). 
in one single HR-management process. This is a situation, which the international praxis and literature explicitly warns against, due to the fact that competency management should be connected to input while performance management is linked to output. Merging them in a single management process is a hopeless undertaking, with many obstacles. ${ }^{17}$

It is a quite strange phenomenon that with the introduction of the new forms of appraisals in the last decade, there exist at present 3 types of appraisal systems in the Hungarian civil service. As the third type of appraisal, called the "evaluation system", has been in place for many years now I will not discuss it in detail here. This evaluation system takes into consideration the results of the performance measurement and other facts, which may be relevant in connection with the work of the civil servant. This "old" evaluation system parallels and overlaps with the other two forms of appraisal currently in place. Taking into consideration the experience gained over recent years, the present setup is a costly, time consuming process, whose functioning has been rather demoralising for civil servants and managers..$^{18}$ It is clear then that in order to make it more efficient it needs to be fine tuned in the future.

Another element already mentioned in connection with the newly applied performance appraisal system is the introduction of competency management in the Hungarian civil service. In recent years competency management has been applied

- as an evaluation criterion of the subsequently introduced personal performance appraisal (bonus) system, and

- as an element of the newly introduced recruitment and selection system.

Below I will briefly describe the new recruitment and selection system of Hungarian civil servants, with the accent on newly introduced elements. As mentioned below, the unified access into the civil service was not regulated in Hungary until recently. As a true novelty, the introduction of the centralized recruitment and selection system, which has taken place gradually since 2008, has been an important and widely discussed change in our civil service legislation. This very detailed and complicated new system has been a step in the direction of a strict career-like system. ${ }^{19}$ According to the legislation in force from 2008 until 2010, applicants wishing to be employed in the civil service must meet the following requirements: ${ }^{20}$

1. the general conditions of acceptance-uniformly regulated for the whole civil service;

17 Horton, S.-Hondeghem, A.-Farnham, D.: Competency Management in the Public Sector: European Variations on a Theme. Amsterdam, 2002.

18 Based on data collected during our research named »The staff of public administration« in the framework of the European Union's Regional Operative Programme 3.1.1 carried out in the Hungarian Institute of Public Administration (leader of the research team: György Gajduschek).

19 While other measures taken at the same time-for example the facilitation of the dismissal of civil servants, or the restraining of the severance pay for them, among others-have broken up the career-like system.

20 After the parliamentary elections in 2010, this newly elaborated recruitment and selection system has been suspended in most of its elements. At the moment (summer 2010) the so-called councours (competitive entering exam) can be passed voluntary, and the competition process is not generally obligatory any more. 
2. the 3-stage competitive entrance exam, the so-called "concours" (1st part: multiple choice test, 2nd part: a set of other types of written examination, 3rd part: oral examination)as a general condition for acceptance;

3. the specific conditions for acceptance-determined for specific posts;

4. the generally obligatory competition procedure (carried out centrally in central administration; and also centrally published at other levels of public administration);

5. the competency evaluation(s)-in certain cases including 3 types of evaluations [a) interviews, b) tests for assessing the suitability of the candidate, c) assessment centres];

6. any further types of assessments when the head of the public administration organ, advertising the vacant post feels it necessary;

7. the generally compulsory half year-probation period. ${ }^{21}$

As the general and specific conditions of acceptance, these are quite similar as those which are in place in the other member states of the European Union, which have a civil service with elements of a career system. From 2009 onwards, passing the "competitive" entrance examination, the so called concours, has also become a general condition for nomination. The design of the newly introduced Hungarian concours was drawn up according to international standards, based on international praxis (on French examples and the praxis of the institutions of the European Communities). In its other fundamental elements, however, it has failed to meet the requirements of a real concours; a real competitive entering examination. In a nutshell, the Hungarian-type concours is not a truly competitive examination. This is due to several factors: First of all, every candidate for a civil service position is required to take the entrance examination, but no provision has been made to ensure that the candidates will be ranked according to the results they achieve. The new central organ responsible for the coordination of the human resources management of the government is able to rank candidates while taking into consideration other factors too (it is not clear exactly how.) In addition, the head of the organisation wishing to fill a vacant post has the right to choose new colleagues at his/her discretion. The other problem has been that all candidates-regardless of their qualification, profession, the post to be filled, etc.-must pass the same examination with the same content. The topic is the same for every candidate. (The only distinction is that people with secondary education have to meet lower requirements ${ }^{22}$ than those with tertiary education.) So, for example a biologist has to compete with a lawyer. Perhaps civil servants in English speaking countries, with completely different administrative cultures (and education systems) may wonder why this is a problem in our country. But in Hungary, with its German-type legal system, where public administration studies are also strictly determined by legal thinking and the knowledge required (also) for this examination is dominated by legal materials, equality of opportunity becomes highly questionable using this method. After functioning for a short period of time, it has become clear that if the "Hungarian-type concours" is to function in the future, this anomaly requires correction.

Competency management is another newly adapted HR-management tool, which has recently been introduced in the Hungarian civil service system. This management tool, first applied to the HR-practice of market oriented companies several decades ago, has been a quite new phenomenon in public administration. In many countries competency management

${ }^{21}$ Linder, V.: A közigazgatás személyi állománya (The Personnel of the Public Administration). In: Kilényi, G. (ed.): A közigazgatási jog nagy kézikönyve (The Big Handbook of Public Administration). Budapest, 2008.

22 In fact the thematic has been less comprehensive for them. 
has gained ground gradually in public organisations, too. Public managers began to feel it necessary to adapt competency management, and use it in the HR-activity of their organisation in order to make it more effective and more responsive to the requirements of modern HR-management. ${ }^{23}$ The most important HR field, where most of these countries-or to be precise most organisations in different countries-have applied competency management is the selection process and the definition of training needs. In this respect, Hungary also fits into the wider trend, and there is no doubt that this management tool can add value and develop traditional approaches in positive ways. But there are some aspects which require further consideration: it is disputable whether competency management should be regulated by law and government decree as it is in Hungary. The real purpose of this management tool is to serve the needs of an organisation according to local circumstances. In order to meet this need it is usually the public managers who decide on its application. It is also unusual, and both theoretically and methodologically questionable that the evaluation of competencies-and what is done with the results of such evaluations-has been directly connected with the process of performance management and with the payment of bonuses (!), as we saw earlier.

As to other elements of the relatively recently introduced, and for the moment suspended unitary selection system (for example the generally obligatory competition), which have tended-from one point of view-to strengthen the civil servants' career system, it remains for the moment unclear, whether they will function in the future and when they do, in which way.

\section{Conclusions}

This article analyses the Hungarian civil service's tentative path between the traditional career and the so-called position-based systems. During the transition period from the communist regime to a democratic rule of law, the legislation of the Hungarian civil service has taken the form of organic civil service legislation, which has regulated the employment relationships of Hungarian civil servants'-in most of its provisions-in a career system. After the millennium, reacting to the modernisation needs of the personnel system of public administration, the Hungarian legislatures introduced a lot of new measures-all of them by legal instructions. The new legal instruments and the amendments of old ones started to change the system in two directions. While some new elements aimed to dismantle the career-like system (for example the introduction of the performance management system and performance related pay, the extending of the possibilities for dismissal, etc.), others have deepened the career-elements (for example the introduction of a new generally obligatory recruitment and selection system-in a detailed and complicated procedure). These very frequent but not at all consistent modifications to civil service legislation have resulted in an incertitude, which has done a lot of damage to the prestige of the civil service. After the new government came to power in the spring of 2010, it is not possible to predict which trend will continue in the future. The only sure thing is that the current decision makers would like to amend-and have already partially amended-the civil service legislation with just the same aims, which motivate the reform processes in all countries of the developed world and which have also been witnessed since roughly the middle of the 1990s in Hungary: cutting the costs of public administration, motivating civil servants and enhancing the capacity and reliability of the civil service in order to better serve the citizens' needs. The newly published solutions must be analysed in another paper.

${ }^{23}$ See Horton-Hondeghem-Farnham: Competency Management in the Public Sector... op. cit. 